\title{
ON AN ELEMENTARY INEQUALITY AND ITS APPLICATION IN THE THEORY OF INTEGRAL EQUATIONS
}

\section{JóZEF BANAŚ AND AgNiESZKA CHLEBOWICZ}

Abstract. An elementary inequality is proved and some special cases of that inequality are discussed. Moreover, the usefulness of that inequality in the theory of some classes of nonlinear integral equations is shown.

Mathematics subject classification (2010): Primary 26D07; Secondary 26A16, 45 G10. tions.

Keywords and phrases: Elementary inequality, integral equation, Banach space, space of Hölder func-

\section{REFERENCES}

[1] K. Deimling, Nonlinear Functional Analysis, Springer, Berlin,1985.

[2] N. Dunford And J. T. Schwartz, Linear Operators I, International Publishing, Leyden, 1963.

[3] M. LoÈve, Probability Theory I, Springer, New York, 1977.

[4] A. Zygmund, Trigonometric Series, Cambridge University Press, Cambridge, 2002.

[5] G. H. Hardy, J. E. Littlewood And G. Pólya, Inequalities, Cambridge University Press, Cambridge, 1952.

[6] D. S. Mitronovič, Analytic Inequalities, Springer, Berlin, 1970.

[7] D. S. Mitronovič, Elementary Inequalities, Noordhoff, Groningen, 1964.

[8] N. K. Ashirbayev, J. Banaś And A. Dubiel, Solvability of an integral equation of VolterraWiener-Hopf type, Abstr. Appl. Anal., vol. 2014, Article ID 982079, 2014, 9 pages.

[9] J. BANAŚ AND R. NALEPA, On the space of functions with growth tempered by a modulus of continuity and its applications, J. Funct. Spaces Appl., vol. 2013, Article ID 820437, 2013, 13 pages.

[10] R. P. Agarwal, J. Banaś, K. Banaś And D. O'Regan, Solvability of a quadratic Hammerstein integral equation in the class of functions having limits at infinity, J. Integral Equats. Appl. 23 (2011), $157-181$.

[11] J. Appell, J. Banaś And N. Merentes, Bounded Variation and Around, Series in Nonlinear Analysis and Applications 17, Walter De Gruyter, Berlin, 2014. 